\title{
MOTIVES OF THE RENAISSANCE ART IN THE WORKS OF BUKOVINIAN ARTISTS OF THE 20th-21st CENTURIES
}

\author{
Iryna Mishchenko \\ Ph.D. of Arts, Associate Professor at the Department of Art Examination, \\ National Academy of Leading Cadres of Culture and Arts, Ukraine \\ e-mail: irynart@ukr.net, orcid.org/0000-0002-3525-5885
}

\section{Summary}

This study examines the works of fine arts of Bukovinian artists, which contain the plot lines, pictorial elements or principles of composition inherent to the works of Renaissance artists. Peculiarities of transformation in painting and graphics of Bukovinian authors of the 20th beginning of the 21 st century of motives and stylistic features of the Renaissance are analyzed. The analysis of the impact of the European visual culture of the 15th-16th centuries allowed tracing the presence of diverse variants and levels of comprehension and application of both the individual elements and the inherent to the aforementioned period the composition-solving principles by numerous authors. The worldview and themes of not only the masters of the Italian Renaissance, but also of the Northern Renaissance, the graphic and painting heritage of artists of the Netherlands and Germany of the end of the 15th-16th centuries, in particular, became the starting point for Chernivtsi artists. In the works one can observe the quoting of certain motives, usage of iconographic schemes, as well as completely different reading of well-known plots, modern interpretation and addition to the latter of new symbols and features of the art of later times.

Keywords: fine arts of Bukovina, Artur Kolnik, Leon Kopelman, Yaroslav Zayats, Gennady Gorbaty.

DOI: https://doi.org/10.23856/4510

\section{Introduction}

The presence of certain influences in the painting and graphics of Northern Bukovina in 20 th- 21 st centuries was quite rarely the subject of study by art critics. This circumstance does not allow speaking about the existence of a sufficiently complete and objective history of the development of fine arts in the region as a whole and a comprehensive description of the stylistic features of the works of individual authors in particular. Ultimately, one of the important aspects of studying the artist's work is to identify the links between the work of a certain master and the culture of the past and the art of contemporaries.

However, the analysis of the diversity of influences on the formation of the worldview of Bukovinian authors has not been properly reflected in the scientific literature. Considerations of semantic and stylistic parallels in the works of artists can be found only in a few publications dedicated to them. This is especially true to the essays published in Bukovinian magazines during the 1910s - 1930s. Since the mid-1920s, the number of articles has increased significantly, with authors trying not only to describe the plot or their impressions, but also to analyze the works, to find parallels between masters of world and Bukovinian art, trends in contemporary music and art. Similar issues were considered by Professor of the Chernivtsi Conservatory P. Jelescu in the publication "Modern Harmony", published in the journal "Junimea literară" 
(Jelescu, 1926). The articles of E. Pohontzu were one of the most interesting, which considered the differences between classical art, impressionism and modernist trends (expressionism, cubism, etc.). Subtly grasping the signs of one or another way of reproducing the world, the author sought to determine the directions to which Bukovinian artists gravitate (Pohontzu, 1925).

M. Kern (Kern, 1935) and the critic Albrich (Albrich, 1932; 1935) published a significant number of interesting reviews of individual works and expositions of Chernivtsi exhibitions, in particular, "Autumn Salons" of the 1930s. Among other materials, V. Zalozieckyj's posts are distinguished by a combination of thorough analysis, emotional presentation and unexpected view. An example is the article "Two paintings - brothers", published in 1932 in the scientific and literary journal "Wandlung" (Zalozieckyj, 1932). One of the few, it contained a detailed artistic analysis of works, between which the art critic sought to find parallels by comparing plot lines and figurative systems of compositions.

During the 1940s - 1980s the issue of influences on the formation of a master's personality was practically not covered. This also applies to the culture of the late Middle Ages, despite the fact that the system of academic education of artists at that time was built on imitation of the forms introduced in the Renaissance. Explorations on the history of visual art of the region were also rare. Among the latter is the work of K. Sanockaya (Sanockaya, 1970). However, due to the ideological limitations of the Soviet era, it is mainly about the influence of Russian culture on the development of art, although such statement seems much exaggerated, because for centuries there were close and active links of Bukovinian art mainly with art and architecture of Western Europe, not Russian empire.

The study of the art history of the region and the consideration of stylistic influences on the formation of artists intensified in the early 2000s. In particular, the ideological principles of O. Shevchukevych's sculpture are considered in T. Dugaeva's book "Sculptor, Doctor of Medicine Opanas Shevchukevych" (Dughajeva, 2002), and the artistic features of E. Lipetsky's works - in the publication "Eusebius Lipetsky. Artist and personality" (Mishchenko, 2004). However, there is still no generalized work that analyzes in detail the variety of influences on the development of Bukovinian art culture of previous eras, in particular, the Renaissance, which proves the need to study the origins of artistic preferences of artists.

The aim of this research is to analyze the works of painting and graphics of Bukovinian artists, in which there are the plot lines, pictorial elements or principles of composition inherent to the works of European Renaissance artists. The research methodology is systemic and historical approaches, application of methods of comparison and generalization, art analysis. The scientific novelty lies in the discovery of the peculiarities of the transformation in Bukovinian art of the 20th - early 21 st centuries of Renaissance motifs, the addition of information about the art of the region in general and the works of individual masters. Important sources of visual information are, first of all, museum and private collections of works, in particular the Chernivtsi Art Museum, which houses a large number of works by Bukovinian authors of the 18 th -21 st centuries.

The late Middle Ages was one of the most important stages in the development of European culture and contributed to the emergence of art in its territory, which included elements of ancient, barbaric and Christian worldviews and differed in a variety of topics, complexity of associations related to literature, journalism, philosophical concepts and religious ideas, the uniqueness of plastic language. E. Rotenberg wrote: "It is difficult to name any other epoch in history after the ancient world, the appearance of which would be so determined primarily by the highest flowering of art" (Rotenberg, 1989: 20). During this period a large number of familiar plots appeared, formed as separate genres, not related to religious compositions and 
portraits, still life, everyday painting and landscape; were created different from the medieval principles of attitude to art as a special and important human activity. As V. Klevaev noted: "The expansion of spiritual horizons gave rise to new forms of reflection of reality in art" (Klevaev, 2007: 198). Over the millennial history of the Middle Ages, the means of expression of art have repeatedly and significantly changed, techniques of execution have appeared and improved, in particular, various types of engraving have appeared. The diversity of stylistic manifestations inherent in this era, the themes of the works proposed by it and the principles of their solution, even today largely determine the artistic orientation of contemporary artists.

The appeals to the visual culture of the Middle Ages in general and the Renaissance in particular are found in the works of many Chernivtsi artists, but they are most pronounced in the graphic sheets of Artur Kolnik and Leon Kopelman, watercolors and etchings by Yaroslav Zayats, paintings by Gennady Gorbaty. Renaissance motifs in the works of these authors are present less in the form of plot lines, but in the principles of spatial composition, the use of individual images, plastic quotations and symbols that create meaningful and stylistic associations with worldviews and artistic principles of the Renaissance.

\section{The graphic of the $1920 \mathrm{~s}$ and $1930 \mathrm{~s}$}

The influence of the art of the late Middle Ages and the German Renaissance is present in the work of one of the most famous Chernivtsi graphic artists of the 1920s and 1930s - Artur Kolnik (1890-1972), a graduate of the Cracow Academy of Fine Arts, where he studied by Józef Mehoffer. This is especially true to A. Kolnik's album "Sous le chapeau haute forme" ("Under the Cylinder"), which consisted of 24 woodcuts and was first published in Paris in 1934 by "Les Ecrivains Reunis". The series of engravings was published in a separate book with a circulation of three hundred and fifteen copies, ten of which were signed by the author. Later, in November 1936, the album with a foreword by the French writer A. Barbusse was published by the Paris publishing house "Ars" with a circulation of a thousand copies, which testifies, in particular, to the relevance of the vision of social development proposed by the artist (Kolnik, 1936). It is also interesting the turn to the technique of woodcut, the spread of which in European art is also associated with the Renaissance.

The engravings of the cycle, marked by the artist's sarcastic attitude to reality, became a tragically ironic and elsewhere full of farce reflection of the life of that time. Depicting various aspects of human existence, the artist pays special attention to political grotesque, turns to anti-religious and anti-war motives, and creates sheets full of witty and sharp observations. The album also includes several compositions that demonstrate the options for the transformation of traditional plots, to which the artist gives a modern sound. Among them are engravings "Golgotha", "The Punished" and "Dance".

In the woodcut "Golgotha" A. Kolnik gives his own interpretation of the theme, without showing the usual for the Renaissance options for carrying the cross, the way to Golgotha or the execution of Jesus. Instead, the graph focuses on the symbolic figures depicted in the foreground - a priest, a gorilla-like policeman and a man in glasses and a hat (possibly a judge), who slowly, with a sense of duty, descends from the hill, leaving a man on his knees tied to a pillar. The association with the traditional plot is strengthened by the presence on the pillar of a plate similar to the one on the crucifixion of Christ. The engraving is distinguished by the conciseness of the compositional solution; all the images in it are presented in general, reflecting the position of the author, emphasizing his attitude to issues of humanity and the contradictions of the social order. 
A. Kolnik returns to the topic of execution in the sheet "The Punished", depicting a woman standing in despair at the feet of a hanged man, hugging a child. The images used in this engraving make it similar to the images of the Madonna and Child and at the same time remind those who are present in the classical solution of the crucifixion scene.

Addressing the theme of "Dance of Death", which was widespread in the European art of the Middle Ages and the German Renaissance, A. Kolnik created an extremely relevant image of the expectation of imminent war. Graphic Death in the form of a skeleton in a gas mask under a cylinder with a torn cape and military boots dances wildly in the middle of the field, where the tanks move. The work "Dance", which concludes the book, is the culmination of the cycle "Sous le chapeau haute forme", because it is perceived as the result of the existence of creatures depicted by the artist, who, according to A. Barbusse, rule everyone behind the scenes of modern history (Kolnik, 1936: 7-9).

This cycle is characterized by emphasizing the predatory nature of most characters or turning them into a shadow-silhouette or mask ("Patriots", "Masquerade News", "Balance", "Shoulder to Shoulder", "Owner"). Such deprivation of human form of these negative characters draws parallels not only to the culture of the Middle Ages and the modern to the author Expressionism, but also to a series of etchings by Francisco Goya "Los desastres de la guerra" ("The Disasters of War"), where the war was portrayed for the first time not in the form of allegorical and romanticized images, but through the discovery of its cruelty, with an openly grotesque, animal-like embodiment of foreign soldiers (Prokofev, 1986). Transforming the established plots of the Renaissance, A. Kolnik combines the features of art of different times - from the late Middle Ages to the romanticism of the 18th - 19th centuries and German expressionism.

The influence of Renaissance art in the 1920s and 1930s is also noticeable in the work of Leon Kopelman (1904-1982), who studied in 1924-1928 painting at the Royal Academy of Arts in Florence. The future artist studied in the studio of Felice Carena, whose influence is quite clear in his works of the time. However, despite studying in Italy, L. Kopelman in his works is stylistically closer to the visual culture of the Netherlands and Germany. Perhaps this is due to the general orientation of the fine arts of Bukovina to the art of Germany and Austria, in whose educational institutions local artists, for the most part, were educated.

One of the critics, talking about the exposition of the "Autumn Salon" in 1932 in Chernivtsi, already then emphasized the similarity of woodcuts of the young artist to medieval engraving, but did not provide the names of works (Bilderausstellung, 1932). Among the graphic sheets of L. Kopelman can be distinguished several groups of works in which such influence is felt most clearly. These include: a series of self-portraits created in 1927-1930, compositions based on evangelical themes of the late 1920s, and the etching "Fossa dell' Abate" of 1926 (all of which are now in the collection of the Chernivtsi Art Museum).

The works of L. Kopelman of that time mostly reflect the renaissance ideal of a free and capable of action individual who asserts himself in society: "The great masters of the 16th century set an example of a new type of artist - an active creative personality, free from the former petty guild restrictions, endowed with the fullness of artistic self-consciousness and able to force to reckon with the strong of this world" (Rotenberg, 1989: 23). Given this, it is not accidental that the artist turns to self-portrait, a genre that spread during the Renaissance, as opposed to the medieval attitude towards the artist as a craftsman, whose name was mostly not even mentioned.

Among L. Kopelman's self-portraits, the etching "Self-portrait with a Flower with the Background of a Landscape" (1927) is the most revealing in terms of the use of the iconic system of the Italian Renaissance and the construction of the composition. It contains characteristic 
to this epoch principles of solving the pictorial space and more imaginary than real image of the "constructed" landscape, which combines all the diversity of the earth's surface. The last feature clearly demonstrates the influence on the formation of a young artist of plastic language of the late Middle Ages. After all, since the 15th century in Italian art the plane of a painting or graphic work acquires a third dimension, and the space depicted in it visually deepens, allowing the artist to reflect in one work the whole world around the human, and consists of specific objects, as opposed to conditional landscape of the earlier times. For the first time, art reflects a disinterested (from the point of view of utilitarianism) admiration for nature, which, however, did not always appear as a favorable environment for human existence. Hence there are the attempts at least in a picture or engraving to depict the ideal world, combining elements of many landscapes - real or created by the imagination of the author. A certain distance between human and nature was emphasized by a special compositional technique, when everything depicted was perceived as if from above and from afar, as a panorama with a clearly defined horizon. Art critic I. Danilova calls this the "view of domination" invented during the Renaissance (Danilova, 1984: 110). Despite the already existing in the practice of artists three-dimensional pictorial space, the characters in such works are still in the foreground and quite clearly separated from the depicted landscape. All these features in their classical embodiment can be seen in the aforementioned self-portrait of L. Kopelman.

An interesting solution to the panorama appears in the self-portrait "Reminiscence" from a series of woodcuts of the late 1920's. Here the author combines architectural monuments from different cities of medieval Italy located in a considerable distance: the baptistery and the dome of the Cathedral of Santa Maria del Fiore in Florence, the Leaning Tower of Pisa and other outstanding landmarks. Thus L. Kopelman, following the masters of the Renaissance, constructs an imaginary landscape, creating the dream ideal world.

To a lesser extent, similar features are present in other engravings of this genre, made by the artist in 1928-1930. In the "Self-Portrait" of 1929, the half-figure of the person portrayed is located between the columns that separate the foreground from the landscape background, creating a characteristic to the Renaissance in the Netherlands window effect, the landscape of which is intended not only for contemplation, but also carries a semantic load.

The "Self-Portrait with a Flower against the Landscape" also uses elements of "vanitas" common in the Renaissance, which reminiscent of the ephemerality of human life and earthly life in general. Symbols of such ephemerality of existence are the flower in the artist's hand, and the image of the cemetery and ruins, the winding river and a tunnel, the smoke of the locomotive and the eclipse of the sun. The inscription on the tombstone becomes both a sign of transience and the artist's signature, as it contains his name, surname, date of birth and mention of his studies in Florence.

In the majority of works of the graphic such a renaissance sense of the world and oneself in it is combined with contemporary manifestations of expressionist art, which appeared in the late 1920's in the works of L. Kopelman and for a long time will determine the style and manner of the artist. Perhaps such a combination was logical for him, because the grotesque, as one of the important means of expressionism, had parallels in the emotionally rich, exalted culture of the late Middle Ages. The same applies to the artist's use of woodcut techniques, popular both in the 15 th and 16 th centuries, and among many German expressionists of the early 20th century.

The combination of features of Renaissance art and expressionism is present in the etching "The Scourging of Christ" in the late 1920's. Here a compositional solution, the use of architectural background, an accentuated alienation from the depicted events of the characters of the background, characteristic of the paintings of Italian masters of quatrocento, are 
organically complemented by the dynamics of foreground figures that clearly outline associations with modern realities. A similar composition is found in Antonello da Messina's work ("Saint Sebastian", 1475-1476, Gallery of Old Masters, Dresden) and Piero della Francesca's ("The Scourging of Christ", ca. 1455-1460, National Marche Gallery, Urbino, Italy). The figures of the townspeople depicted next to the scenes of martyrdom by these two authors are similar. Although in dealing with the figures of those who insult Christ, L. Kopelman is much closer to the dynamic figures of Luca Signorelli's paintings ("The Scourging of Christ", 1475 (1482-1485), Pinacoteca di Brera, Milano; "The Scourging of Christ”, 1507, Lindenau Museum, Altenburg), especially to the scene of the scourging from the predella "Removal from the Cross" ("The Scourging of Christ", 1502, Museo Diocesano, Cortona).

Interpreting the medieval compositions of the plots "The Martyrdom of St. Sebastian" or "The Scourging of Christ", the author emphasizes them by the underlined emotionality of expressionist manifestations. The characteristic to the Renaissance sense of balance in the engraving by L. Kopelman is destroyed by the rapid movement of figures in the foreground, forming a kind of funnel, in the center of which is a column with the figure of Christ. Massive, dense in tone figures of "bald" with whips in the hands contrast with the calm lines of the architectural environment and generalized silhouettes of people in the background. In this etching, associations with real events in Italy at the time are combined with the author's philosophical reflections on why one dares to be a Human, while others turn into a faceless aggressive crowd or vague figures of those who do not try to resist the evil. Renaissance pictorial motifs here reflect the impressions and silent protest of the artist, who, while in Italy, observed the emergence of fascism in Europe and repeatedly addressed the theme of its emergence and reactions of the society to it (sheet "Unterhaltung" ("Conversation")) from a series of self-portraits, 1928-1929). A similar modernization of classical themes is characteristic to the artist's drawings with Christological motifs ("Rest on the way to Egypt", 1920-1930; "Passions of Christ", 1931, Chernivtsi Art Museum), in which the influence of the paintings of the Netherlands of the 15 th century is palpable, with its inherent grotesque.

The appeal to the artistic heritage of the Renaissance in the artist's work is limited to the 1930s, because after the annexation of Northern Bukovina to Soviet Ukraine in 1940, he will work mainly on landscapes of Chernivtsi and the Carpathians, make caricatures for newspapers and industrial graphics. Instead, a significant part of the mentioned works will not even be exhibited till the posthumous exhibition of graphics in 1994 at the Chernivtsi Art Museum; they will not be included to any of the life catalogs of L. Kopelman.

\section{The Art of the 20th-21st century}

Among modern authors, Renaissance motifs are most often found in the graphics of Yaroslav Zayats (b. 1951), a graduate of the Faculty of Graphics of the Kyiv State Art Institute (now the National Academy of Fine Arts and Architecture). In works of this master, conciseness and formal expressiveness of the solution are achieved, in particular, through numerous images-symbols, which, due to their universality, become both the embodiment of national motifs and universal archetypes, and carriers of common concepts and images for many European cultures. The latter are often associated with the Middle Ages and the Northern Renaissance. Philosophical, associative and stylistic parallels, internal kinship with the works of Dutch artists of the "Renaissance without Antiquity" can be felt in Y. Zayats' watercolors and etchings. Among them closest to him are the painters Hieronymus van Aken (Bosch) and Pieter Bruegel the Elder. We can assume that this consonance of ideas and motives is due to coincidences in 
the historical development of countries. After all, the ambiguity of today in Ukraine is somewhat reminiscent of the political situation in which the Netherlands was in the 15th and 16th centuries.

The researcher of Dutch art B. Vipper identifies as notable features of the Renaissance in the Netherlands a heightened sense of spatial indivisibility of depicted phenomena and events, awareness of their material and emotional connection and the associated interest in the air, subtle tonal and color relationships (Vipper, 1957: 21). Y. Zayats, like the masters of that era, perceives the world in its inseparable unity with a human, as really visible and close, and, at the same time as inaccessible to human understanding, cosmos created by God. Perhaps the most distinctive in his works was the influence of P. Bruegel the Elder, whose artistic ideas are closely linked to the medieval worldview, folklore and allegory, and the paintings are characterized by a bizarre combination of reality and phantasmagoric.

The works of the modern graphics contain the insight and spirituality of Bruegel's epic compositions, his inherent cosmic understanding of the world (hence - and a high horizon line that allows the eye to comprehend a large space), the all-encompassing nature of the artist's perception of reality. However, the majority of Y. Zayats's works lack the tragedy and grotesque inherent to the paintings of the Dutch painter; the harmony of the coexistence of nature and human is emphasized instead. In general, the influence of the art of the past is an important feature of the artistic language of works, giving a special sophistication and expressiveness to the created images, but, nevertheless, is only part of the complex and ambiguous thinking of the modern author. Borrowing certain plots or principles of compositional construction, as well as largely echoing the worldview of the past, reproducing elements of a style, the master always saturates them with his own vision, uses the plastic language of his time.

An example of such an artistic transformation is the watercolor "The yard of my childhood" (1984), in which everyday life is compared with the existence of the universe. The closed space of the courtyard, accentuated by the frontal solution of the composition with the backstage objects that reveal the action scene to the viewer, is combined with the surrounding world, recreated in a garden panorama with a constant path in the background and a barely visible swallow in height. In this sheet the quiet joy of everyday life with attention to the smallest and seemingly inconspicuous elements (the variability of the sun's rays on the wall of the house, colored glass in the window, bouquets of dried flowers and kitchen utensils) is shown. However, in the watercolor of Y. Zayats, for all its detail, the photographic, deceptive similarity of images to natural objects is avoided. The generalizations concern not only the meaningful plan of the work, but also the means of expression used in it, when the contours of the depicted objects soften, dissolving in the strokes of multi-layered scales.

The influence of P. Bruegel the Elder work is most noticeable in Y. Zayats' watercolor "Snow Fall" (1982), in the compositional solution of which parallels with the "Winter Landscape" and "Hunters in the Snow" by the Dutch author can be traced. The latter in his picture creates a deep, detailed panorama, on the left in the foreground placing a group of hunters. Y. Zayats also has a group of two boys and a woman with a child in the lower left corner of the sheet. However, Bruegel's hunters are dynamic, active in color; they stand out in a clear silhouette in the snow, setting the linear rhythm of the whole work. Instead, in the work of the Ukrainian graphic artist, the figures of people almost merged in color and tone with their surroundings, they froze in their movement - like a stopped moment of life. And all around is the infinity of a seemingly enchanted winter space - the Universe, in which a human is only a part of the silence that he is not allowed to break. 
The dynamics characteristic to numerous scenes of peasant dances (kirmes) and holidays by Dutch masters are also present in Y. Zayats' watercolor "Wedding" (1984). However, when constructing the composition, the Ukrainian graphic spatially and tonally emphasizes a certain detachment from the events unfolding next to him. And only once his work surprises with the inherent to the kirmes of Dutch painters unrestrained movement ("Dance”, 1997).

The combination of motifs of medieval culture and modern vision is also present in the poster he painted for the theatrical performance of G. Boccaccio's Decameron (1984). Based on a Renaissance-inspired literary work, the watercolor very accurately reflects the character of the novels imbued with humor and irony, life-affirming power and observation, in no way literally repeating the plot lines of the book.

The composition as a whole evokes semantic associations with the central part of the triptych by H. Bosch "Hay cart" (ca 1516 (1500-1502), Prado National Museum, Madrid), which, like the huge apple in the poster of Y. Zayats, became the embodiment of earthly life with its hustle and bustle, from which everyone seeks to get a piece. In H. Bosch the side parts of the triptych depict heaven and hell. In the work of the modern artist the futility of human hopes and the transience of life, the inevitability of punishment for sins is symbolized by the figure of an angel who cuts off part of an apple with a knife, approaching the end of earthly existence. However, the work of the Ukrainian author, despite the dramatic or tragicomic accents, still has a more optimistic sound. It is full of irony of a witty narrator, each motive in the interpretation of which is part of the whole and at the same time a self-sufficient plot. Among them is a replica of the famous painting by one of the founders of classicism N. Poussin and a mocking image of a pious girl, a duel of the men, a knife sharpener and a tired and desperate angel. And behind the hustle and bustle of the apple there is a calm and gentle landscape and dynamic sky, which loved to depict also Dutch painters.

Combining in the sheet the classic background landscape drawn in small strokes and the fantastically paradoxical image of an apple in the center, the artist saturates his work with a significant number of eloquent details, each of which clarifies the idea. This is how a lock appears, which does not shut anything, while remaining a sign of the forbidden fruit, and a clock without arrows - as a sign of the timeless existence of the depicted plots and characters of the people.

The graphic artist most often addresses the theme of the Nativity of Christ, sometimes combining in the composition the iconography of various plots of the Christological cycle and the image of Ukrainian folk customs. Y. Zayats seems to emphasize the somewhat contradictory coexistence in the presence of elements of the late antique, barbaric and Christian worldview, which formed the foundations of modern European culture during the early Middle Ages at a new stage of human development.

Similar motifs are present in the toned etching "Christmas" (1991), in which there is a characteristic to Dutch culture of the 15 th -17 th centuries, traditional icon painting and Ukrainian folk art, combination of time-divided events, transfer of classical motifs and characters to the present, phantasmagoric combination of different plans. This work depicts the Biblical Magi who came to worship the baby, the characters from Ukrainian Christmas rites of Malanka and carols, ordinary peasants and a shepherd, and Jesus carrying the cross. In the iconography of Christ, the affinity with the works of artists of the Dutch Renaissance is especially noticeable. The work is full of details, each of which is significant and expresses the philosophical concept of the author. It is no coincidence that the symbols of the Eucharist appear in the composition - a chalice and bread on a white canvas spread on straw, earth fruits scattered in the snow, reminiscent of the symbolic still lives of Hugo van der Goes in the scenes of worship of the newborn Jesus. Almost out of nowhere the ladder appears near the figure of the Madonna, leads nowhere, 
and then repeats in the background, creating associations with the famous plot of Jacob's dream. However, all the other characters become only the background, the frames of the film that captures the events. Instead, the most important are the figures of Mary with the baby and the image of a cow, with a metal bell on her neck and a Hutsul carpet-kilim on her back, leaning towards the child, separating the whole group from the procession in the background. By Y. Zayats the image of a cow not only reminds of the characters of the Nativity scene, but also symbolizes the earthly life. After all, as V. Klevaev notes, in many peoples of Europe the cow is a personification of one of the elements of the universe, and them are four: fire, air, water and earth. The earth is an element that was associated with a melancholy temperament" (Klevaev, 2007: 545).

The image of the Mother of God with the baby is also present in the composition "Night" created in 1989, where the image suddenly acquires the likeness of a mystical medieval action, the center of which is the figure of Mary. Around her unfolds a dramatic extravaganza of figures and faces of people, images of animals and storks, turning into the embodiment of the fall into hell, over which above are the quiet and sad figures of a peasant couple and a cross. The symbolism of the details, as well as the mood of the work, reminiscent the medieval reliefs and paintings by many masters with scenes of the Last Judgment and the image of hell-darkness, in which people disappear.

Visual comparisons of pagan and Christian symbols are interesting in the works of the graphic. Thus, in the figures of the composition "Divination" (2007) appear the images of the solar sign and the sleepless eye, the girl-Eve and the Mother of God of Great Panagia, which at the same time is the embodiment of the artist's native Ukrainian region of Pokuttya. The ornaments applied on top of the image act here as a visible sign of ancient beliefs. The female images created by the artist often resemble Eve or Danaë of the Renaissance, while retaining purely national features, which can also be seen in the connection with the principles of Renaissance art (cycle of works “Autumn”, early 2000's).

Addressing the plots and motifs of European art of the 15th -16 th centuries and using unexpected combinations of images of that time, archetypes and complex associations, traditional and new artistic techniques, Y. Zayats creates a self-sufficient system of signs and plastic metaphors of postmodernism. Notable for the master's works is their semantic multidimensionality, which leads to a variety of reading works, engaging the viewer in the intellectual game offered by the artist, full of allegories, visual parallels and symbols.

The influence of Renaissance art is manifested in a different way in the painting of Gennady Gorbaty (b. 1955), a graduate of the Faculty of Painting of the Kyiv State Art Institute (now the National Academy of Fine Arts and Architecture), who worked in Chernivtsi in 1987-1992 and now lives in Germany. Characteristic to him is a frequent combination of motives and plot lines on the art of the past and the perception of modern man within one work, emphasizing the sensual principle ("Danaë", 2009).

A similar solution is noticeable in "Three Graces" (2009), which combines elements of "Judgement of Paris", "vanitas" and images of harites, while the artist seeks primarily to emotionally saturate the canvas, to make a more expressive play of colors and textures. The motif "vanitas" repeatedly appears in the paintings of this author, such as "Dance of the Butterflies" (1992), in variations of "Magic Signs" (1998), recalling the ephemerality of youth and the transience of human existence.

It is possible to trace how the artist's approach to the use of pictorial elements of the Renaissance changed on the example of a number of works of 1992-2009, based on the image of the Garden of Eden. If in the early canvas "Adam and Eve" (1992), for all the conditionality of the plastic solution, the associations given by the forms and range of red and black tones 
are easy to read, therefore later the works become multilayered in content, more complex in developing a picturesque surface ("Tree of knowledge", 1994). In this picture, the earthly existence, presented as a lifeless desert with a lonely unstable temple and a lonely human figure, is contrasted with the Garden of Eden, symbolized by a tree with apples falling generously on the cracked ground. The figure of Eve here almost merges with the trunk, as if arising from a texture resembling a snakeskin. The expression, reflected through the contrasts of pasty, color-active spots and translucent planes of light local tones, emphasizes the feeling of energy that is released, as if tearing the surface of the canvas. As in other works by G. Gorbaty, paradise is not the embodiment of harmony, but a place of confrontation and conflict ("Garden of Eden", 1998; "Garden of Eden I", 2009), and is reproduced primarily by the confrontation of colors and dynamic textures.

The personification of the contradictions and drama of the earthly existence is the canvas "Babylon" (1993-1994), in which the tower, which diagonally crosses the surface of the painting, leaves a trace of its own destruction, becoming a phantom of ideas, a symbol of futility. And the barely outlined generalized silhouettes of people seem unstable and amorphous, changeable, like waves enveloping the disappearing contours of the tower.

Addressing the images of both the Italian Renaissance and the Northern Renaissance, G. Gorbaty transforms them, leaving, for the most part, only a hint of the recognizable symbols of this era and paying attention, above all, to the creation of an active, pulsating picturesque surface, which embodies the feeling of inner anxiety and emphasizes the sensory principle in the artist's perception of the world.

\section{Conclusions}

The analysis of the works of several masters who worked in Chernivtsi during the 20th-21st centuries allows us to talk about the variety of options for their use of artistic heritage of the Renaissance - from borrowing storylines and quoting individual motifs, reproduction of stylistic features - to the complete transformation of images, which leads to the emergence of a more complex and multidimensional work, in which the Renaissance style is complemented by features of art of later eras. Some artists turn to the culture of the Italian Renaissance (L. Kopelman, G. Gorbaty), others rethink the principles of art of the Northern Renaissance - especially the Netherlands and Germany (A. Kolnik, Y. Zayats). However, each of the authors demonstrates an organic combination in his works of the principles of solving the compositions of the late Middle Ages and modern artistic manifestations.

Thus, the graphics of A. Kolnik and L. Kopelman are characterized by a fusion of the plots of the Middle Ages and the aesthetics of expressionism. Instead, Y. Zayats seeks to find the accuracy of plastic expressions through semantic and visual parallels, the complex symbolism of Dutch art of the 15th and 16th centuries and the elements of Ukrainian traditional culture. For G. Gorbaty the very poetic and emotional basis of the myth is important, and the plastic ideas and pictorial motifs of the Renaissance act as a stimulus to one's own search for a sensual interpretation of such a myth.

Using various sources, these artists reflect changes in the perception of certain classical works, complementing the ancient motifs with their own reading and arguing that the influence of Renaissance heritage on contemporary art is an important factor in forming new meanings and enriching the plastic solution of compositions. Therefore, the existence of such artistic parallels requires further analysis in order to understand the essence of the interaction of elements of different epochs of cultural development. 


\section{References}

Kern, M. (1935). Zeugen der Bucovinaer Vergangenheit (Im Museum "Regele Carol II") [Witnesses of the Bucovina past (in the museum "Regele Carol II")]. Czernowitzer Allgemeine Zeitung. 26. Dezember. [in German]

Bilderausstellung (1932). [Picture exhibition]. Czernowitzer Morgenblatt, 9. October. [in German]

Rotenberg, E. (1989). Iskusstvo Italii 16-17 vekov [Art of Italy 16-17 centuries]. Moskva: Sovetskij hudozhnik. [in Russian]

Klevaev, V. (2007). Lekcii po istorii iskusstva [Lectures on the history of art]. Kiev: Fakt. [in Russian]

Prokofev, V.N. (1986). Gojya v iskusstve romanticheskoj epohi [Goya in the art of the romantic era]. Moskva: Iskusstvo. [in Russian]

Albrich (1932). Herbstsalon Bukowinaer Künstler [Autumn Salon of Bucovina artists]. Czernowitzer Allgemeine Zeitung. 8. October. [in German]

Albrich (1935). Der Herbstsalon (Die Ausstellung im Museum) [The autumn salon (the exhibition in the museum)]. Czernowitzer Allgemeine Zeitung. 15. Dezember. [in German]

Zalozieckyj, W. (1932). Zwei Bilder-Brüder [Two picture brothers]. Wandlung. H. 1. [in German]

Danilova, I. E. (1984). Iskusstvo srednih vekov $i$ Vozrozhdeniya [Art of the Middle Ages and Renaissance]. Moskva: Sovetskij hudozhnik. [in Russian]

Dughajeva, T. (2002). Skuljptor, doktor medycyny Opanas Shevchukevych [Sculptor, doctor of medicine Opanas Shevchukevich]. Chernivci: Zelena Bukovyna. [in Ukrainian]

Mishchenko, I. (2004). Yevzebii Lipetskyi. Mystets i osobystist [Eusebius of Lipetsky. Artist and personality]. Chernivtsi: Misto. [in Ukrainian]

Mishchenko, I. (2011). Rysy ekspresionizmu v dorobku bukovynskykh khudozhnykiv pershoi polovyny XX stolittia [Features of expressionism in the works of Bukovinian artists of the first half of the twentieth century]. Studii mystetstvoznavchi, 4. [in Ukrainian]

Mishchenko, I. (2008). Secesija v mystectvi Bukovyny [Secession in the art of Bukovina]. Studiji mystectvoznavchi, 1 (21). [in Ukrainian]

Sanockaya, K. I. (1970). Ukrainskoe izobrazitelnoe iskusstvo Severnoj Bukoviny konca XVIIInach. XX st. [Ukrainian fine art of Northern Bukovina late XVIII - early XX century]. Kiev: IMFYe. [in Russian]

Kolnik, A. (1936). Sous le chapeau haute forme [Under the high form hat]. Paris: Editions „ARS”. [in French]

Jelescu, P. (1926). Armonia Modernă [Modern Harmony]. Junimea literară. № 1-2. [in Romanian]

Pohontzu, E. (1925). Cronica artistică. Plastica [Artistic chronicle. Plastic]. Junimea literară. № 5-7. [in Romanian]

Vipper, B. R. (1957). Stanovlenie realizma v gollandskoj zhivopisi XVII veka [The emergence of realism in Dutch painting of the 17th century]. Moskva: Iskusstvo. [in Russian] 